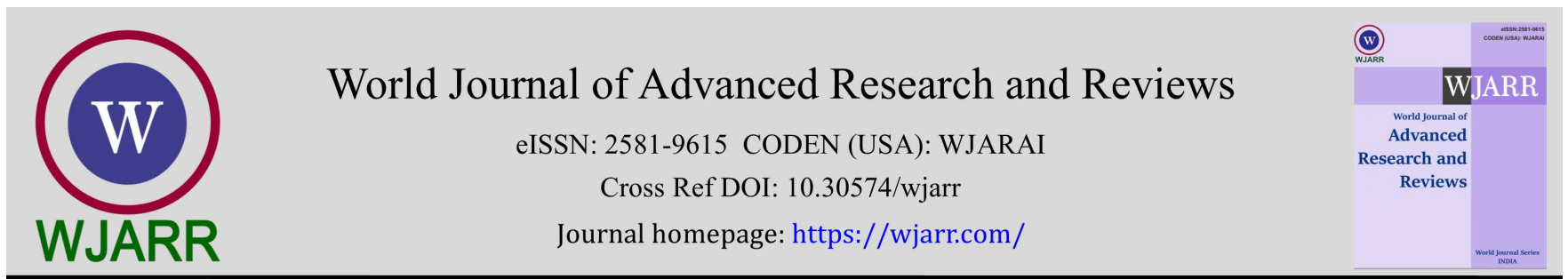

(RESEARCH ARTICLE)

\title{
Fish species biodiversity of Dadin-Kowa reservoir: Current status
}

\author{
Nazeef $\mathrm{S}^{1,}{ }^{*}$, Ja'afar A ${ }^{2}$, Abubakar KA ${ }^{2}$ and Kabiru $\mathrm{M}^{1}$ \\ ${ }^{1}$ Department of Biological Science, Gombe State University, P.M.B 127, Gombe. \\ 2 Department of Zoology, Modibbo Adama University, Yola.
}

World Journal of Advanced Research and Reviews, 2021, 11(02), 100-111

Publication history: Received on 03 July 2021; revised on 08 August 2021; accepted on 10 August 2021

Article DOI: https://doi.org/10.30574/wjarr.2021.11.2.0370

\begin{abstract}
The fish composition of the three study sites of the reservoir were studied over a period of fifteen months (January, 2020 - March, 2021). A total of twenty-eight (28) fish species emanating from fourteen (14) families were obtained. The family Cichlidae was the dominant family with Oreochromis niloticus being the most abundant fish species while family Malapteruridae was the least with only $0.088 \%$ of the total abundance. Biodiversity indices of the study sites such as species richness ranges from 2.79-3.28, while species evenness ranged between 0.73 to 0.84 , and diversity index revealed a range of 2.23-2.65. The Dadin-Kowa Reservoir has a rich ichthyofaunal composition which is facing challenges of structural collapse unless if management strategies are fully adopted. The host communities should be made integral components of aquatic resources management team. And other means of livelihood should be made attractive to reduce pressure on aquatic resources and deter possible biodiversity depressions.
\end{abstract}

Keywords: Fish composition; Oreochromis niloticus; Dadin-Kowa reservoir; Cichlidae; Malapteruridae

\section{Introduction}

A fish refers to a vertebrate that lives, breath and breed in water ${ }^{1}$. Aquatic ecosystem has been estimated to make up 8-9\% of the earth's land surface ${ }^{2}$. This made it an important source of fish because of their species richness and unique biodiversity ${ }^{3}$; this vast uniqueness has make it possible for fish species to serve as important sources of employment ${ }^{4}$, leisure ${ }^{5-7}$, income and trading opportunity ${ }^{8}$.

Fishery sector is the largest and fastest food growing (economy) industry in the world 9,10. Fisheries and aquaculture serves a source of food and income to about 820 million individuals globally ${ }^{11}$. Small scale fisheries (SSF) and aquaculture provide two thirds of the catches destined for human consumption which account for $90 \%$ of employment in the sector (Welcomme, 2019). So therefore human societies face enormous challenge of having to provide food and sources of livelihoods to a population well in excess of nine (9) billion people (FA0, 2019).

The collective production of global protein as reported by ${ }^{12}$, indicated that fish contributed significantly $19.86 \%$ (marine catches) and 17.77\% (aquaculture), while freshwater produces only 2.3\% with cichlids (87\%) and cyprinids forming the most prominent groups of the inland fishery production ${ }^{13}$. Global fish production peaked at about 171 million tonnes in 2016 with aquaculture representing $47 \%$ of the total and $53 \%$ of non-food uses (including reduction to fishmeal and fish oil) ${ }^{11}$.

The precise number of extant fish species is yet to be determined, however according to ${ }^{14}$, there were about 28,900 species globally, though this figure bears considerable doubt as some experts feel that the number may be higher. In

\footnotetext{
* Corresponding author: Nazeef S

Department of Biological Science, Gombe State University, P.M.B 127, Gombe.

Copyright $(2021$ Author(s) retain the copyright of this article. This article is published under the terms of the Creative Commons Attribution Liscense 4.0.
} 
today's diversity; it is estimated to have 34,300 species globally (www.fishbase.org 2020). This number forms about $51 \%$ of the 54,711 living vertebrate species recognized ${ }^{15}$.

Inland fisheries including Nigeria for decades has been a driving force of economies of most countries of the world contributing to the country's GDP ${ }^{16}$. Inland fisheries are rooted in socially and culturally complex societies ${ }^{17}$; they play a vital role in the livelihood of people in many parts of the developed and developing world ${ }^{11,17}$ including Nigeria. At present, inland fisheries are not often a national or regional governance priority and as a result, inland capture fisheries are undervalued and largely overlooked ${ }^{2}$. There's increasing number of fish catch globally ${ }^{18}$ and aquatic ecosystem is subject to and can be altered by a range of ecological stressors ${ }^{3}$ which can have an impact on fish population that are subject to natural control processes ${ }^{19}$. And this includes habitat destruction, alterations ${ }^{20}$ and uncontrolled exploitation 21. Freshwater ecosystems represent one of the most threatened broad habitats globally despite containing around a third of all vertebrates ${ }^{22,23}$ due to increasing human population, socio-economic development which led to a severe pressure being placed on the freshwater ecosystem globally 23 .

Biodiversity is a concept to ecology and its measurements is essential to ecosystem health ${ }^{24}$; due to wide variations of ecosystems in distribution, abundance, dominance and biodiversity levels (Omayio and Mzungu, 2019). In a functional diversity context; richness is understood to increase or enhance community functionality and complexity (increases in productivity) (Daly, Baetens, and Baets 2018; Nazeef, 2017). Species richness in sub-lakes was assumed to be positively associated with water depth and aquatic habitat availability with connectivity; in all which increase in wet season 27. Besides species richness which receives prominent attention however, evenness is also ecologically important as it portrays been a key factor in preserving functional stability of ecosystem as well as improving productivity by enhancing representation of each species' functional traits or characteristics, contrary however, community's uneven dispersion pattern tend to have less resilience to disturbance and environmental stresses $24,26,28$. A central issue in community ecology is understanding and predicting the structure of species assemblages and their spatio-temporal variations across multiple scales ${ }^{27}$.

\section{Material and methods}

\subsection{Study Area}

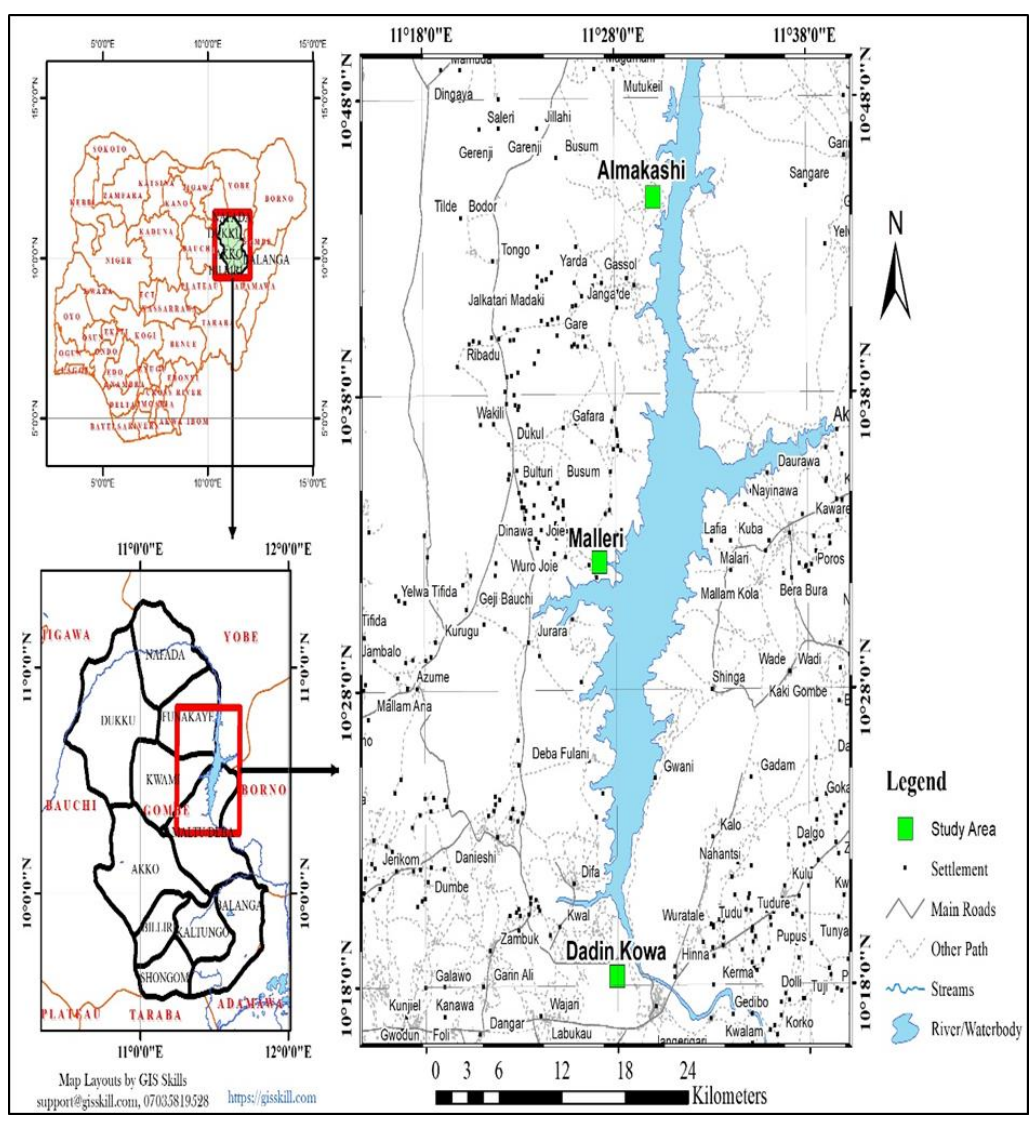

Figure 1 Map of Dadin-Kowa showing study area 
The Dadin-Kowa is located in Yamaltu-Deba Local Government area, Gombe State in the north east of Nigeria. Dadinkowa town is located between Latitudes $10^{\circ} 19^{\prime} 19^{\prime \prime} \mathrm{N}$ and $10.32194^{\circ} \mathrm{N}$; Longitude $11^{\circ} 28^{\prime} 54^{\prime \prime} \mathrm{E}$ and $11.48167^{\circ} \mathrm{E}$. It shares common boundary with Akko Local Government area, to the South and West, Yamaltu-Deba to the East and Kwami to the North. Dadin-kowa has an altitude of about 370 meters above sea level ${ }^{29}$.

\subsection{Data Collection}

Fish samples were collected from three of the four prominent landing sites on a monthly basis for the period of 12 months (January - December, 2020) from artisanal fishermen. The three landing sites were: Almakashi: $10^{\circ} 44^{\prime} 40.584^{\prime \prime} \mathrm{N}$,

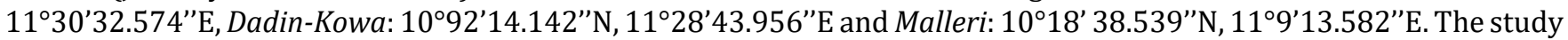
area has bordered three local government areas of Gombe State each with at least a town having intensive fishing activities, therefore, the aforementioned landing sites were selected reflecting the entire Reservoir coverage, and the local government areas includes Funakaye (Almakashi); Yamaltu-Deba (Dadin-Kowa) and Kwami (Malleri) accordingly.

\subsection{Fish Samples Collection and Identification}

Fish samples were sampled from the population and their morphometric measurements (Standard length \& weight) were measured using a measuring tape and a digital weighing balance (Sartorius) to the nearest $0.1 \mathrm{~cm}$ and $0.1 \mathrm{~g}$ respectively, following the methods explained by (Ahmad, et al., 2017). Identification of fish samples to the species level was accomplished using identification keys such as Reeds et al, (1967), Olaosebikan \& Raji (2004) and fishbase.org (identification keys and fish species global glossary).

\subsection{Ichthyofauna composition and Diversity}

The ichthyofaunal composition of the Reservoir was estimated from the checklist of fishes obtained from identification of monthly samples. Some indices of diversity were used to describe the diversity of the fish communities in the Reservoir as follows:

\subsubsection{Margalef's Index (D)}

for species richness (Margalef, 1968).

$\mathrm{D}=(\mathrm{S}-1) / \ln \mathrm{N}$

Where

$\mathrm{S}=$ number of species and

$\mathrm{N}=$ number of individuals.

\subsubsection{The Shannon-Wiener's Index ( $\left.H^{\prime}\right)$}

of species diversity (Shannon \& Wiener, 1963);

$\mathrm{H}^{\prime}=-\Sigma \mathrm{Pi} \operatorname{Ln} \mathrm{Pi}$

Where $\mathrm{Pi}$, is the proportion of the total number of individuals occurring in species $\mathbf{i}$.

\subsubsection{Pielou's Index (J)}

for species evenness (Pielou, 1969);

$\mathrm{J}=\mathrm{H}^{\prime} / \mathrm{Ln} \mathrm{S}$

Where $\mathrm{H}^{\prime}$ is the species diversity index and $\mathbf{S}$ is the number of species.

Other alpha biodiversity indices such as Dominance_D, Simpson_1-D, Fisher-alpha, Berger-Parker, and Menhinick were assessed employing the Diversity option of PAST software (Version 4.03) ${ }^{30 .}$

\section{Results}

\subsection{Fish Species Identified}

A total of twenty-eight (28) fish species were identified from the three study sites (Almakashi, Dadin-Kowa and Malleri) over a twelve months' period (January to December, 2020), is presented on table one. These fish species represent a 
total of fourteen (14) families (Table 1). The family Mormyridae had the highest species representation with six fish species (viz Hyperopisus bebe, Hyperopisus bebe occidentalis, Mormyrus rume, Mormyrus macrophthalmus, Marcusenius senegalensis and Pollimyrus isidori). The family Alestidae ranked second with four (4) fish species (which includes Alestes dentex, Alestes leuciscus, Brycinus nurse and Brycinus macrolepidotus), while family Bagridae (with Auchenoglanis occidentalis; Bagrus bayad macropterus and Bagrus docmac) and family Cichlidae (having Oreochromis niloticus; Sarotherodon galilaeus and Tilapia zilli) co-ranked third in the list with three species each, but family Cyprinidae and Schilbeidae co-ranked fifth with two species each, while Citharinus citharus; Clarias lazera and Synodontis budgetti singly represented the families Citharinidae, Claridae and Mochokidae.

Table 1 Fish species identified from the three study sites

\begin{tabular}{|c|c|c|c|}
\hline Family & Fish species & English name & Local name (Hausa) \\
\hline \multirow[t]{4}{*}{ Alestidae } & Alestes dentex & Silversides & Saro \\
\hline & Alestes leuciscus & & Kursa \\
\hline & Brycinus nurse & African tetras & Kawara \\
\hline & Brycinus macrolepidotus & African tetras & Kakara \\
\hline \multirow[t]{3}{*}{ Bagridae } & Auchenoglanis occidentalis & Catfish & Buro \\
\hline & Bagrus bayad macropterus & Silver catfish & Ragon ruwa/Doza \\
\hline & Bagrus docmac & Semutundu & Dinko/Musko \\
\hline Characidae & Hydrocynus brevis & Tigerfish & Tsage \\
\hline \multirow[t]{3}{*}{ Cichlidae } & Oreochromis niloticus & Tilapia & Karfasa \\
\hline & Sarotherodon galilaeus & Tilapia & Karfasa \\
\hline & Tilapia zilli & Tilapia & Gargaza \\
\hline Citharinidae & Citharinus citharus & Moonfish & Faliya \\
\hline Claridae & Clarias lazera & Catfish & Tarwada \\
\hline \multirow[t]{2}{*}{ Cyprinidae } & Labeo brachypoma & African carp & Data \\
\hline & Labeo senegalensis & African carp & Burdo \\
\hline Distichodontidae & Paradistichodus dimidiatus & Grasseater & Dandubi \\
\hline Malapteruridae & Malapterurus electricus & Electric fish & Minjirya \\
\hline Mochokidae & Synodontis budgetti & Wahrindi & Kurungu \\
\hline \multirow[t]{6}{*}{ Mormyridae } & Hyperopisus bebe & & Kuma \\
\hline & Hyperopisus bebe occidentalis & Trunkfish & Tola \\
\hline & Mormyrus rume & Bottlenose & Sawayya \\
\hline & Mormyrus macrophthalmus & Trunkfish & Miligi \\
\hline & Marcusenius senegalensis & & Kuma mai lebe \\
\hline & Pollimyrus isidori & & Dunguru \\
\hline Polypteridae & Erpeitoichthys calabaricus & Snakefish & Gartsa \\
\hline \multirow[t]{2}{*}{ Schilbeidae } & Parailia pellucida & Glassfish & Nama-waje \\
\hline & Schilbe mystus & Butterfish & Lulu/Balo \\
\hline Sisoridae & Glyptothorax exodon & & Yauka-yauka \\
\hline
\end{tabular}




\subsection{Cumulative Percentage of Fish Species Abundance from the Three Study Sites}

The cumulative abundance and percentage abundance of each of the fish species from the three (3) study sites is presented on table two (2). The table showed that Sarotherodon galilaeus had the least abundance percentage with $0.02 \%$ of the total catch. While Marcusenius senegalensis; Malapterurus electricus, Brycinus macrolepidotus, Erpeitoichthys calabaricus, Tilapia zilli, Hyperopisus bebe occidentalis, Labeo brachypoma, Paradistichodus dimidiatus, Bagrus docmac, Citharinus citharus, Glyptothorax exodon and Mormyrus macrophthalmus had 0.04-0.92\% accordingly (Table 2). Whereas the rest of the fish species with the exception of Oreochromis niloticus; had an abundance percentage within the range of $1.58-8.88 \%$. The highest abundance was recorded from the cichlid Oreochromis niloticus with $30.83 \%$ (Table 2).

Table 2 Cumulative abundance percentage of the fish species across study sites

\begin{tabular}{|c|c|c|c|c|c|}
\hline Fish Species & Almakashi & Dadin-Kowa & Malleri & Total & \% Abundance \\
\hline Alestes dentex & 117 & 50 & 71 & 238 & 5.22 \\
\hline Alestes leuciscus & 20 & 42 & 116 & 178 & 3.90 \\
\hline Brycinus nurse & 71 & 62 & 43 & 176 & 3.86 \\
\hline Brycinus macrolepidotus & 1 & 4 & 0 & 5 & 0.11 \\
\hline Auchenoglanis occidentalis & 34 & 59 & 32 & 125 & 2.74 \\
\hline Bagrus bayad macropterus & 94 & 72 & 32 & 198 & 4.34 \\
\hline Bagrus docmac & 0 & 32 & 1 & 33 & 0.72 \\
\hline Hydrocynus brevis & 56 & 6 & 19 & 81 & 1.78 \\
\hline Oreochromis niloticus & 836 & 147 & 424 & 1407 & 30.83 \\
\hline Sarotherodon galilaeus & 0 & 0 & 1 & 1 & 0.02 \\
\hline Tilapia zilli & 9 & 0 & 1 & 10 & 0.22 \\
\hline Citharinus citharus & 37 & 0 & 2 & 39 & 0.85 \\
\hline Clarias lazera & 101 & 105 & 174 & 380 & 8.33 \\
\hline Labeo brachypoma & 4 & 5 & 9 & 18 & 0.39 \\
\hline Labeo senegalensis & 72 & 17 & 39 & 128 & 2.81 \\
\hline Paradistichodus dimidiatus & 0 & 9 & 9 & 18 & 0.39 \\
\hline Malapterurus electricus & 0 & 4 & 0 & 4 & 0.09 \\
\hline Synodontis budgetti & 94 & 164 & 61 & 319 & 6.99 \\
\hline Hyperopisus bebe & 66 & 70 & 5 & 141 & 3.09 \\
\hline Hyperopisus bebe occidentalis & 7 & 1 & 5 & 13 & 0.28 \\
\hline Mormyrus rume & 32 & 30 & 10 & 72 & 1.58 \\
\hline Mormyrus macrophthalmus & 24 & 9 & 9 & 42 & 0.92 \\
\hline Marcusenius senegalensis & 2 & 0 & 0 & 2 & 0.04 \\
\hline Pollimyrus isidori & 0 & 0 & 154 & 154 & 3.37 \\
\hline Erpeitoichthys calabaricus & 0 & 4 & 2 & 6 & 0.13 \\
\hline Parailia pellucida & 189 & 28 & 188 & 405 & 8.88 \\
\hline Schilbe mystus & 214 & 44 & 70 & 328 & 7.19 \\
\hline Glyptothorax exodon & 14 & 19 & 9 & 42 & 0.92 \\
\hline
\end{tabular}




\subsection{Fish Species Family Abundance Composition}

The fish species family abundance of the three study sites is presented on table three (3). With only 4 individuals of the fish species Malapterurus electricus; the family Malapteruridae had the least representation with only $0.088 \%$, while the family Cichlidae with a total of one thousand, four hundred and eighteen (1418) individuals had 31.07\% of the total catch of the studies; this is followed by family Schilbeidae with $16.06 \%$ with seven hundred and thirty-three (733) cumulative individuals. Family Alestidae had $13.08 \%$ and Mormyridae $9.29 \%$ accordingly. The remaining families had less than $9.0 \%$ of the total fish stock (Table 3 ).

Table 3 Fish Species Family Abundance Composition

\begin{tabular}{|l|c|c|}
\hline Family & Total Individuals Per Family & Percentage Abundance Per Family \\
\hline Alestidae & 597 & 13.083 \\
\hline Bagridae & 356 & 7.802 \\
\hline Characidae & 81 & 1.775 \\
\hline Cichlidae & 1418 & 31.076 \\
\hline Citharinidae & 39 & 0.855 \\
\hline Claridae & 380 & 8.328 \\
\hline Cyprinidae & 146 & 3.200 \\
\hline Distichodontidae & 18 & 0.394 \\
\hline Malapteruridae & 4 & 0.088 \\
\hline Mochokidae & 319 & 6.991 \\
\hline Mormyridae & 424 & 9.292 \\
\hline Polypteridae & 6 & 0.131 \\
\hline Schilbeidae & 733 & 16.064 \\
\hline Sisoridae & 42 & 0.920 \\
\hline
\end{tabular}

\subsection{Fish Species Biodiversity indices of the Three Study Sites}

Table 4 Fish Species Biodiversity Parameters of the Three Study Sites

\begin{tabular}{|l|c|c|c|}
\hline \multirow{2}{*}{ Biodiversity Parameter } & & Study Sites & \\
\cline { 2 - 4 } & Almakashi & Dadin-Kowa & Malleri \\
\hline Number of fish species identified & 22 & 23 & 25 \\
\hline Number of families identified & 11 & 13 & 13 \\
\hline Numeric volume of fish sampled & 2094 & 983 & 1486 \\
\hline Margalef's index (D) of species richness & 2.75 & 3.19 & 3.28 \\
\hline Shannon-Wiener's index (H) of species diversity & 2.23 & 2.65 & 2.37 \\
\hline Pielou's index (J) of species evenness & 0.732 & 0.846 & 0.736 \\
\hline Taxa_S & 22 & 23 & 25 \\
\hline Dominance_D & 0.1922 & 0.8887 & 0.1364 \\
\hline Simpson_1-D & 0.8078 & 0.9111 & 0.8636 \\
\hline Evenness ^^/_s $^{\wedge}$ & 0.4228 & 0.610 & 0.425 \\
\hline Brillouin & 2.209 & 2.6 & 2.335 \\
\hline Menhinick & 0.4808 & 0.7336 & 0.6485 \\
\hline Fisher_alpha & 3.429 & 4.215 & 4.27 \\
\hline Berger-Parker & 0.3992 & 0.668 & 0.2853 \\
\hline
\end{tabular}


The indices of biodiversity such as the Margalef's index (D) of species richness; Shannon-Wiener's (H) of species diversity and Pielou's index of species evenness (J) for the study sites is presented on table four (4). Site Malleri had the highest species richness (D) with a value of 3.28, followed by Dadin-Kowa with 3.19, where Almakashi ranked third with richness value 2.75. Shannon-Wiener's index $(\mathrm{H})$ of species diversity indicated that Dadin-Kowa ranked first with a value of 2.65; followed by Malleri with 2.37 and Almakashi with 2.23 accordingly. Pielou's species evenness (J) indicated a value of 0.846 for Dadin-Kowa site, followed by Malleri study site with 0.736 and lastly Almakashi with 0.732 accordingly (Table 4). Other biodiversity indices such as Dominance_D, Simpson_1-D, Menhinick and Berger-Parker indicated that Dadin-Kowa study site had the prominent index values, while Malleri ranked first in the chart in respect to Fisher_alpha biodiversity index (Table 4).

\section{Discussion}

\subsection{Fish Species Diversity and Abundance}

In this study; twenty-eight (28) fish species originating within fourteen (14) families from the three landing sites of the study area were identified. Cichlids and schilbeids were the dominant fish groups. The fish species composition of this study agreed with the findings of ${ }^{31}$ who recorded 28 fish species in New Calabar. Twenty-seven (27) fish species were documented from Kalgwai river (Jigawa State, Nigeria) by ${ }^{32}$ and Gilo river (Ethiopia) ${ }^{33}$. However; despite this great conformities, the outcomes of this study yielded lesser fish species biodiversity as compared to other studies such as eighty-three species documented from Jebba (Hydro - Electric Plant) in Nigeria ${ }^{19}$. In line with this category; fifty (50) fish species were also reported from Taraba river ${ }^{34}$. Thirty-five (35) fish species enumerated from Agenebode, Edo State ${ }^{35}$. In non-African countries; ${ }^{36}$ reported 69 fish species emanating from Buenaventura Bay (Columbia), whereas 39 fish species were encountered from Palordi river (Bangladesh) by ${ }^{37}$. Following the trend, one hundred and twentyfive (125) fish species were encountered from Cambodia's Mekong river 38 but only eighty-four fish species were documented from the China's giant Ganjiang river by ${ }^{39}$. The Dadin-Kowa fish species complex is however considered to exceed the outcomes of other study areas such as the eleven (11) fish species obtained from Lake Victoria Basin, Kenya ${ }^{40}$, Tiga dam also produced nine (9) fish species ${ }^{41}$, but Upper Benue River accounted for twenty-six fish species as reported by ${ }^{42}$. And emanating from New Calabar river ${ }^{43}$ enumerated similar findings, but ${ }^{44}$ recorded eighteen (18) fish species from Asejire reservoir, Nigeria. The differences in fish species representation of Dadin-Kowa reservoir as compared to other study areas may be attributed to the differences in lake-basin morphometry, moderate exploitation, food sources, photo-period, reservoir size, riverine tributaries, seasonal migration 26,38. While river abstraction, dynamics of hydrological regimes, fish species adaptation to lotic environment, geographical position, environmental, habitat quality, species number vary depending upon differences in sampling methods and sampling effort, as well as fish abundance $34,38,40,45$.

The present study indicated that Dadin-Kowa reservoir harbors a total of fourteen (14) fish families; this family composition is in line with the findings of other researchers such as ${ }^{46}$ who reported 15 fish families from New Calabar, Zira et al. (2017) reported 15 fish families from Kiri reservoir. Whereas ${ }^{48}$ recorded fifteen (15) families from Donga river Taraba State. This is similar to the sixteen (16) families enumerated from Upper Benue (Nigeria) ${ }^{42}$. Olopade et al. (2020b) reported 15 fish families from New Calabar. Going across African lakes and water confinements, Hu et al. (2019b) recorded 15 families from China's Ganjiang lake. Besides these outstanding accords, the fish family composition of Dadin-Kowa reservoir illustrated contrary accordance to the outcomes of other lakes and water confinements such as Otammiri river where 10 families were recorded ${ }^{50}$, with the documentation of 28 expected fish families from Pendjari river, Lake Volta. Going by this family variations; Pius et al. (2020) identified 20 fish families in Taraba river. Tiga dam (Kano State) also hosted seven fish families ${ }^{41}$. Whereas 29 families emerging from Buenaventura Bay were encountered 36. This differences were also strengthened by the eleven (11) and twelve (12) fish families enumerated from New Calabar ${ }^{43}$ and Asejire reservoir ${ }^{44}$ accordingly.

The susceptibility of a fish species to a fishing gear is likely linked with the habitat of fish species; unlike non-riverine system, riverine aquatic ecosystems are characterized with fluctuations of increasing species abundance, diversity and richness ${ }^{45}$. Habitats differences in species abundance can be as result of differences of sediments accumulation which serves as a precursor to food generation and liberation. Additionally; environmental factors such as salinity and suspended particles, natural or anthropogenic causes can definitely bring differences in the composition of fish species and families ${ }^{36}$.

The present study inferred that Dadin-Kowa Reservoir is dominated with four main categories of fish groups or families precisely. These families include Cichlidae (31.08\%, but Oreochromis niloticus singly made up 30.83\%), this is followed by Schilbeidae (16.06\% combined, Parailia pellucida, and Schilbe mystus), then Alestidae (13.08\%) with four species, mormyrids constituted six fish species making up 9.26\%, and lastly Claridae with Clarias lazera being the sole 
representative constituting 8.32\%. The dominance of cichlids especially Oreochromis niloticus from this study is in agreement with numerous outcomes of other studies across Nigeria, this includes the works of Oladipo et al. (2021), Solomon et al. (2017), ${ }^{1}$ from Omuechi stream, Pius et al, (2020), Abdulkarim et al, (2020), Dienye et al, (2018), Olopade (2020) and Omoike, (2021) all recorded the dominance of cichlids. This dominance of cichlids is attributable to quite a number of outstanding factors which includes high proliferation and being the second most diverse family of freshwater fish ${ }^{52}$ with global distribution ${ }^{53}$. This assertion was supported by Leveque (1997) in Olopade (2020) who stated that "cichlids are the most diverse fish family in Africa. Good parental care (mouth brooding as found in some species such as Tilapia galilaeus), high rates of juveniles, adult survival, strong competitive capabilities ${ }^{46}$, diverse feeding protocols, high population in response to predation and other forces of population decay, while adaptation to both lotic and lentic ecosystem, productivity and changes to hydrological regimes 19,26 are considered the unique features warranting the dominance of Oreochromis niloticus. Besides cichlids; schilbeids formed the next highly abundant group with $16.06 \%$ combined. This outstanding abundance is attributed to their adaptability to diverse feeding protocols, moderate body size in relation to growth speed, moderate level of fecundity, availability of macrophytes and debris as sources of nutrition ${ }^{34}$. Alestids which includes major players such as Alestes dentex and Brycinus leuciscus also bear similar living strategist as of the schilbeids especially prolific capacities as they serve as dietary source (ecological niche) to other trophic levels such as the African pike (Hepsetus odoe) which warrants their diversified sustainability. Mormyrids on the hand in this study bears six species with a total of $9.26 \%$ of the entire fish abundance composition, Pollimyrus isidori being the most abundant in this category indicated that this species advanced due to food availability, relative smallsize with potentially high growth capacity enables this fish species to attain maturity in short span of time and ultimately high prolific nature. The family Claridae constituted the last category of highly abundant fish species, Clarias lazera singly represented the family with an abundance percentage of $8.32 \%$ of the total fish catch. It was understood that this fish species has an outstanding records of high proliferation, hardy in nature with abilities to resist broad set of diseases, possession of atmospheric air breathing accessories, ability to withstand oxygen deficiencies in turbid waters and soft bottoms ${ }^{36}$ and their generalist feeding features which implies that food is not a limiting factor ${ }^{40}$.

Contrary to the aforementioned abundance capabilities, the cichlid species Sarotherodon galilaeus alongside Malapterurus electricus in this study were documented to bear the least fish abundance. The dwindling population of Sarotherodon galilaeus might be linked to a possible local extinction of this fish species, only one individual was recorded in the month of June; as there is no restocking programs for the restoration of this species. The fish species is palatable just as in other cichlids, therefore also a possible tendency to its high demand which resulted in its population declination below its exploitation threshold or it might be possible that this fish species was on spawning migration or refuge seeking when it was captured. The family Malapteruridae was represented singly by Malapterurus electricus, only few individuals were documented in this study which coincided with outcomes of ${ }^{54}$ and contrast that of 55 ; implying a very low fecundity, poor competitive strengths, least public demand and that its dietary requirement is salty which can be obtained at reservoir bottoms almost beyond the reach of a fishing gear, for refilling its defensive architecture of electric current, the meat of this species is considered salty and less palatable, thereby attracting the least public interest and hence can be classified as Least Concern (LC).

Generally, it can be understood that fish species abundance and its possible fluctuations are associated with fish harvest intensity, gears used, downstream migration, commercial and domestic water usage, fish shelter, and spawning 42 , habitat morphology and hydrology (including water retention and recession) ${ }^{54}$, unethical fishing practices such as the use of minute mesh-size nets ${ }^{44}$, targeting of spawning biomass (especially mega-spawners) ${ }^{56}$. These factors can alter the structure and composition of any fish community including reservoirs.

\subsection{Fish Species Biodiversity Indices}

The four main biodiversity indices of the Dadin-Kowa were considered for discussion in this section; thus this includes Margalef's species richness (D), Shannon-Weiner's species diversity (H), Pielou's index of species evenness (J) and Dominance_D accordingly. The present study indicated a peak species richness of 3.28. This index score contrasts the score reported from Jebba $(D=9.73){ }^{19}$, but higher than the outcome from Konoskhaihaor river, Bangladesh ${ }^{57}$. This result was lower than 4.0 as recorded by ${ }^{58}$.

The Dadin-Kowa inferred a peak value of 2.65 of species diversity (H), which is lesser than 3.94 accounted by 19 from Jebba dam, 3.12 as documented by ${ }^{57}$. But this index is higher than the reported score from Raya water ${ }^{59}$; despite this valid variations, the Dadin-Kowa reservoir is said to have attained a moderate species diversity. This is because according to Kreb's index (1989) in ${ }^{59}$, species diversity index of greater than 1 and less than 3 is said to be moderate.

The species evenness (J) of this study is documented as 0.84 , this value is in line with 0.83 recorded from Gubi Dam ${ }^{60}$. This is relatively greater than the recorded values from Lagos Coastal waters 61, Riau Province, Indonesia 62 and 
Lakhandaha reservoir 63. Reference to Kreb's guidelines; the present outcome of this study is said to have a stable community since species evenness is greater than 0.75 , although less than 1 (one) ${ }^{59}$.

Dominance_D which reflects on the domination of one fish species that is more dominating than others indicated that the current outcome is relatively greater than the outcomes accounted for from Jebba ${ }^{19}$. Dominance is inversely proportional to diversity index, therefore the lower the value of dominance, the richer the diversity ${ }^{59}$.

The fluctuations of diversity, uniformity and dominance of fish communities portrays the influence of physical, chemical and food factors ${ }^{59}$. Fish species had been observed to be influenced by cumulative impacts of aqua-cultural activities such as water quality degradation, intensified intra and inter specific competitions, invasive species and habitat defragmentation ${ }^{62}$ but damming or river abstraction ${ }^{64}$ alongside water recession and sample size 57 strengthened the justification for the fluctuations of fish species richness including Dadin-Kowa reservoir. However, it was noted that latitude (especially low) increase both size and species diversity of fish communities, this is further supported by lake depth which was observed to contribute to the variations of diversity, probably because deep lakes tend to have larger space with habitat heterogeneity to accommodate wide range of fish species, this followed the Habitat Diversity Hypothesis which states "that diversity is controlled by the availability of different habitats" 65.

\section{Conclusion}

The Dadin - Kowa Reservoir is said to have a good ichthyofaunal composition coupled with twenty-eight fish species belonging to fourteen families. Biodiversity indices conformed to Kreb's guidelines which revealed moderate species diversity $(\mathrm{H}=2.65)$ and stable community $(\mathrm{J}=0.84)$.

\section{Compliance with ethical standards}

\section{Acknowledgments}

The authors wish to express their appreciation to Gombe State University, as well as the fishermen communities of the Dadin-Kowa reservoir and its tributaries. Our sincere gratitude goes to TET Fund Nigeria for providing the financial opportunity to conduct such exercise.

\section{Disclosure of conflict of interest}

All authors declares that there is no conflict of interest.

\section{References}

[1] Manasirli M, Mavruk S, Yeldan H, Avsar D. Population Dynamics of Suez Pufferfish (Lagocephalus suezensis) in Population Dynamics of Suez in Iskenderun Bay. Turkish J Fish Aquat Sci. 2020; 20(10): 749-754.

[2] Cooke SJ, Allison EH, Beard TD, et al. On the sustainability of inland fisheries: Finding a future for the forgotten. Ambio. 2016; 45(7): 753-764.

[3] Robinson LA, Blincow HL, Culhane FE, Higgins OT. Identifying barriers, confl ict and opportunity in managing aquatic ecosystems. Sci Total Environ. 2019; 651: 1992-2002.

[4] Abubakar UM. Diversity and Condition Factor of Fish Species of Dadin Kowa Dam, Gombe By. 2012.

[5] Froese R, Winker H, Coro G, et al. Original Article A new approach for estimating stock status from length frequency data. ICES J Mar Sci. 2018; 75: 2004-2015.

[6] Babali N, Kacher M, Belhabib D, Louanchi F, Pauly D. Recreational fisheries economics between illusion and reality: The case of Algeria. PLoS One. 2018; 13(8): 1-11.

[7] Meirelles K, Freire F, Belhabib D, et al. Estimating Global Catches of Marine Recreational Fisheries. Front Mar Sci. 2020; 7(12): 1-18.

[8] Freire KMF. Brazilian recreational fisheries: current status, challenges and future direction. Fish Manag Ecol. 2016: 1-15. 
[9] Manikandarajan T, Mahadevan G, Pouladi M. Growth parameters and length-weight relationship of Heniochus acuminatus (Linnaeus, 1758) (Perciformes : Chaetodontidae) from the Southeast coast of India. Iran J Ichthyol. 2019; 6(March 2020): 271-282.

[10] Roy A, Dutta S, Podder A, Homechaudhuri S. Variation in Population Characteristics and Harvesting Pressure Influencing Recruitment Pattern of an Economically Important Fish, Osteomugil cunnesius of Indian Sundarbans. Proc Zool Soc. 2019.

[11] FAO. FAO publications catalogue. 2019.

[12] Welcomme RL. An overview of global catch statistics for inland fish. ICES J Mar Sci. 2011; 68(8):1751-1756.

[13] FAO. Freshwater Small Pelagic Fish and Fisheries in Major African Lakes and Reservoirs in Relation to Food Security and Nutrition. 2019.

[14] Nsor CA, Obodai EA. Fish Community Structure and Diversity in Two Distinct Seasons among Wetlands of Northern Region ( Ghana ). Hindawi Int J Ecol. 2016.

[15] Leveque C, Oberdorff T, Paugy D. Global diversity of fish (Pisces) in freshwater. Hydrologia. 2008; (April): 545567.

[16] Famoofo 00, Abdul WO. Heliyon Biometry, condition factors and length-weight relationships of sixteen fish species in Iwopin fresh-water ecotype of Lekki Lagoon, Ogun State, Southwest Nigeria. Heliyon. 2020; 6(January 2019): e02957.

[17] Bartley D, Jorgensen J, Marmulla G. The scale of inland fisheries, can we do better? Alternative approaches for assessment. Fish Manag Ecol. 2015; (22): 64-70.

[18] Porch C, Bryan M, Brodziak J, et al. Estimating Total Mortality Rates from Mean Lengths and Catch Rates in Nonequilibrium Situations. Trans Am Fish Soc. 2017; 146(04): 803-815.

[19] Oladipo SO, Nneji LM, Iyiola OA, et al. Patterns of ichthyofaunal diversity and distribution across Jebba HydroElectric Power (HEP) dam, Jebba, north-central Nigeria. Brazilian J Biol. 2021; 81(2): 258-267.

[20] Yerima R, Bolorunduro P, Suleiman B, Usman L. Temporal Variation of Fish Species Composition, Abundance and Diversity in relation to Physicochemical Characteristics of Dadin Kowa Reservoir Gombe State-Nigeria. Int J Appl Res. 2017; 8(2): 149-165.

[21] Nazeef S, Yola IA, Ahmed IM. Relative Yield Indices of Challawa Gorge Dam, Kano State, Nigeria. Greener J Biol Sci. 2017; 7(6): 060-062.

[22] Cooke SJ, Twardek WM, Lynch AJ, et al. A global perspective on the influence of the COVID-19 pandemic on freshwater fish biodiversity. Biol Conserv. 2021; 253(September 2020): 108932.

[23] Holland RA, Darwall WRT, Smith KG. Conservation priorities for freshwater biodiversity: The Key Biodiversity Area approach refined and tested for continental Africa. Biol Conserv. 2012; 148(1): 167-179.

[24] Daly AJ, Baetens JM, Baets B De. Ecological Diversity : Measuring the Unmeasurable. Mathematics. 2018 ; 6: 2-28.

[25] Omayio DO, Mzungu E. Modification of Shannon-Wiener Diversity Index towards Quantitative Estimation of Environmental Wellness and Biodiversity Levels under a Non- comparative Scenario Modification of ShannonWiener Diversity Index towards Quantitative Estimation of Environmen. J Environ Earth Sci. 2019; 9(October).

[26] Nazeef S. Evaluation of Fish Biodiversity and Yield Potentials of Challawa Gorge Dam, Kano State, Nigeria. 2017.

[27] Jin B, Ge G, Winemiller KO, Shao B, Si J, Jin J. Fish assemblage structure in relation to seasonal environmental variation in sub- lakes of the Poyang Lake floodplain, China. Fish Manag Ecol. 2019; (June 2018): 131-140.

[28] Abdulkarim M, Yusuf ZA, Suleiman S, Lamai S, Magaji I. PRELIMINARY STUDIES ON THE BIODIVERSITY OF FISH SPECIES IN GWARAM AND SHELAN RIVERS IN MISAU , BAUCHI -NIGERIA PRELIMINARY STUDIES ON THE BIODIVERSITY OF FISH SPECIES IN. Fish Soc Niger. 2019; 16(1).

[29] Nazeef S, Abubakar UM. Diversity and Condition Factor of Fish Species of Dadin Kowa Dam, Gombe State, Nigeria. Greener J Biol Sci. 2013; 2012(April 2018).

[30] Gosavi SM, Kharat SS, Kumkar P, Tapkir SD. Assessing the sustainability of lepidophagous catfish, Pachypterus khavalchor (Kulkarni, 1952), from a tropical river Panchaganga, Maharashtra, India. J Basic Appl Zool. 2019; 9(80): 1-10. 
[31] Olopade OA, Dienye HE, Bamidele N, Oderhohwo O. CATCHABILITY AND DIVERSITY OF FISH SPECIES CAPTURED BY GILL NET IN NEW CALABAR RIVER, NIGERIA. Indones Fish Res J. 2020; 26(2): 107-117.

[32] Solomon SG, Ayuba VO, Tahir MA, Okomoda VT. Abundance Composition of Fish In Lake Kalgwai Jigawa State, Nigeria. Jordan J Agric Sci. 2017; 13(1): 45-54.

[33] Tut G, Wakjira M, Tamire G. Diversity, Length-Weight Relationship and Condition Factor of Fishes in Gilo River and its Nearby Wetlands in Akobo District, Gambella Region, Ethiopia. J Fish Sci. 2019; 13(1): 19-28.

[34] Pius DE, Ja'afaru A, Abubakar KA, Zira JD, Kefas M, Barau BW. FISH BIODIVERSITY AND ABUNDANCE IN RIVER TARABA, TARABA STATE, NIGERIA. Ethiop J Environ Stud Manag. 2020; 13(5): 535-544.

[35] Onwude A, Fran A, Abel I, Eric O. Biodiversity of Fish Fauna in River Niger at Agenebode, Edo State, Nigeria. Egypt J Aquat Biol Fish. 2019; 23(4): 159-166.

[36] Molina A, Duque G, Cogua P. Influences of environmental conditions in the fish assemblage structure of a tropical estuary. Mar Biodivers. 2020; 50(5): 1-13.

[37] Kar D, Hossen S, Sharker R, et al. Impact of Island on Fish Diversity and Fisherman Community in Palordi River, Bangladesh. Middle-East J Sci Res. 2020; 28(4): 286-295.

[38] Pin K, Nut S, Hogan ZS, et al. Cambodian Freshwater Fish Assemblage Structure and Distribution Patterns: Using a Large-Scale Monitoring Network to Understand the Dynamics and Management Implications of Species Clusters in a Global Biodiversity Hotspot. Water. 2020; 12: 1-25.

[39] Hu M, Wang C, Liu Y, Zhang X, Jian S. Fish species composition, distribution and community structure in the lower reaches of Ganjiang River, Jiangxi, China. Sci Rep. 2019; 9: 1-13.

[40] Mwangi BM, Ombogo MA, Amadi J, Baker N, Mugalu D. Fish Species Composition and Diversity of Small Riverine Ecosystems in the Lake Victoria Basin, Kenya. Int J Sci Technol. 2012; 2(9): 675-680.

[41] Abdulkarim M, Magaji IM, Yusuf ZA, Magaji NS. DIVERSITY AND SPATIO-TEMPORAL DISTRIBUTION OF FISH SPECIES IN TIGA DAM, KANO STATE. Niger J Fish. 2020; 17(1): 1969-1972.

[42] Bonjoru R, Abubakar KA, Hassan EI, Jerry TJ. Diversity and Abundance of Fish Species in Some Selected Riverine Wetlands of Upper Benue River Basin , Nigeria. IOSR J Environ Sci Toxicol Food Technol. 2019; 13(8): 8-13.

[43] Dienye HE, Olopade OA, Toby SA. SPECIES COMPOSITION AND DIVERSITY OF CAST NET FISHERIES IN NEW CALABAR, NIGER DELTA, NIGERIA. J Biodivers Conserv Bioresour Manag. 2018; 4(1): 19-26.

[44] Omoike A. The Trend in Fish Species Diversity and Abundance at Asejire Reservoir South Western Nigeria. HSOA J Aquac Fish. 2021; 5(040): 1-9.

[45] Olopade OA, Dienye HE, Bamidele N, Oderhohwo O. CATCHABILITY AND DIVERSITY OF FISH SPECIES CAPTURED BY GILL NET IN NEW CALABAR RIVER, NIGERIA. Indones Fish Res J. 2020; 26(2): 107-117.

[46] Olopade OA, Dienye HE, Oderhohwo O. Fish species composition and size structure exploited by gill net fishery in New Calabar River, Nigeria. Acta Aquat. 2019; 6(1): 1-6.

[47] Zira J, Pius DE, Bature Adamu A, Bubabadgal E. Fish Species Diversity and Abundance of Kiri Reservoir, Shelleng Local Government Area, Adamawa State, Nigeria. Int J Res Agric For. 2017; 4(10): 24-30.

[48] Amos JT, Ja'afaru A, Abubakar KA. An Assessment and Identification of Fish Species Abundance and Endangered in River Donga Taraba State, Nigeria. Direct Res J Agric Food Sci. 2020; 8(February): 62-66.

[49] Hu M, Wang C, Liu Y, Zhang X, Jian S. Fish species composition, distribution and community structure in the lower reaches of Ganjiang River, Jianxi, China. Sci Rep. 2019; (June): 1-13.

[50] Ude EF, Udoimuk S. Preliminary investigation of fish species abundance of Otammiri River, Owerri, Nigeria. In: Proceedings of 28th Annual Conference of Fisheries Biology. 2013; 25-30.

[51] Tonye IA, Mavis O. Composition and Diversity of the Fish Fauna of Omuechi Stream, Aluu, Rivers State, Nigeria. IOSR J Environ Sci Toxicol Food Technol. 2017; 11(1): 34-39.

[52] Seehausen 0. Process and pattern in cichlid radiations - inferences for understanding unusually high rates of evolutionary diversification. New Phytol. 2015; 207: 304-312.

[53] Abobi SM, Alhassan EH, Abarike DE, Atindana S, Akongyuure DN. Species composition and abundance of freshwater fishes from the lower reaches of the White Volta at Yapei, Ghana. J Biodivers Environ Sci. 2014; 4(4): $1-5$. 
[54] Mo A, Garba AA, Mshelia JP. Diversity and abundance of fish species in river Okpokwu, Benue state, Nigeria. Int J Fish Aquat Stud. 2019; 7(6): 55-60.

[55] Essien-Ibok MA. Fish fauna of Akwa Ibom State inland waters. Biodivers Int J. 2020; 4(2): 82-88.

[56] Gebremedhin S, Bruneel S, Getahun A, Anteneh W, Goethals P. Scientific Methods to Understand Fish Population Dynamics and support sustainable fisheries management. Water. 2021; 13: 1-20.

[57] Iqbal MM, Kanon MH, Hossain MA, et al. Diversity of indigenous fish species in Konoskhaihaor, Northeast Bangladesh. Punjab Univ J Zool. 2015; 30(2): 73-79.

[58] Hepner ME. Reef Fish Biodiversity in the Florida Keys National Marine Sanctuary. 2017.

[59] Ulfah M, Fajri SN, Nasir M, Hamsah K, Purnawan S. Diversity, evenness and dominance index reef fish in Krueng Raya Water, Aceh Besar. In: IOP Conference Series: Earth and Environmental Science. 2019.

[60] Ataguba GA, Tachia MU, Aminu. Fish species diversity and abundance of Gubi Dam, Bauchi State of Nigeria. Biol Divers Conserv. 2014; 2: 1-9.

[61] Bamidele BJ, Timothy O. The Species Composition and Diversity of the Coastal Waters of Badagry, Lagos State, Nigeria. Int J Res Agric For. 2016; 3(4): 1-5.

[62] Aryani N, Suharman I, Azrita A, Syandri H, Mardiah A. Diversity and distribution of fish fauna of upstream and downstream areas at Koto Panjang Reservoir, Riau Province, Indonesia [ version 2 ; peer review : 2 approved ]. F1000Research. 2021; 1-17.

[63] Jewel A, Haque A, Khatun R, Rahman S. A Comparative Study of Fish Assemblage and Diversity Indices in two Different Aquatic Habitats in Bangladesh : Lakhandaha Wetland and Atari River. Jordan J Biol Sci. 2018; 11(4): 427-434.

[64] Gownaris NJ, Rountos KJ, Kaufman L, Kolding J, Lwiza KMM, Pikitch EK. Water level fl uctuations and the ecosystem functioning of lakes. J Great Lakes Res. 2018; 44(6): 1154-1163.

[65] Brucet S, Arranz I, Mehner T, et al. Size diversity and species diversity relationships in fish assemblages of Western Palearctic lakes. Ecography (Cop). 2018; 41: 1064-1076. 